\title{
Explaining the Mixed Outcomes from Hosting Major Sporting Events in Promoting Tourism
}

José I. Rojas-Méndez

Professor of International Business \& Marketing

Sprott School of Business, Carleton University

Dunton Tower 925,

1125 Colonel By Drive,

Ottawa,

Ontario,

Canada K1S 5B6

Tel: +1 613520 2600x8014

Email: jose.rojas@carleton.ca

Gary Davies

Professor of Business Strategy

University of Chester

Business Research Institute

Riverside Campus

Chester

$\mathrm{CH} 1$ 4BJ

Tel: +44 (0)1244678668

Email gary.davies@chester.ac.uk

Jutatip Jamsawang

Department of Marketing

Faculty of Business, Economics and Statistics

University of Vienna, Austria

Email: Jutatip.Jamsawang@univie.ac.at

José Luis Sandoval Duque

Professor of Strategic Management

Facultad de Ciencias Económicas y Administrativas

Universidad Cooperativa de Colombia

Bogotá, Colombia

E-mail: jose.sandovald@ucc.edu.co

Gina M. Pipoli

Professor of Marketing

Department of Business Administration

Graduate School at the Universidad del Pacífico,

Lima, Peru

E-mail: pipoli_gm@up.edu.pe 


\title{
Explaining the Mixed Outcomes from Hosting Major Sporting Events in Promoting Tourism
}

\begin{abstract}
We report on a study of the longitudinal effects of the 2014 World Cup on the host Brazil's overall image and for tourism intentions in three other countries (total sample $=207$ ). Brazil's image declined significantly 2013-2014 on some but not all measures and improved amongst a significant minority. The mixed outcomes are explained by the moderating effects of respondent personality, their involvement in the event (rather than in the sport being hosted) and their perception of the news they had been exposed to. Those who held a relatively negative attitude towards Brazil before the event tended to be positively influenced by positive media, watching the closing ceremony and by searching for news about Brazil. Those relatively high in Openness to Experience were less likely to report a reduction in attitude. The net effect was an improvement in tourism intentions, mainly among those less likely to visit pre-event and a decline among most others.
\end{abstract}

Key words: Sports Sponsorship, Tourism intention, Country image, Brazil, World Cup, Media Valence, Openness to Experience 


\section{Highlights}

-There can be marked differences in how the same mega event influences individuals

- Media comment can explain changes to overall perceptions of the host, but may not explain differences in tourism intention

- Involvement in the global event better explains differences in outcomes than an involvement in the sport itself.

- Those with a high Openness to Experience personality tended to maintain any positive imagery they held pre-event

-Those with a relatively negative/positive country image pre- World Cup reported a more positive/negative image post-event. 


\section{Explaining the Mixed Outcomes from Hosting Major Sporting Events in Promoting Tourism}

\subsection{Introduction}

Holding an international sports event such as the Olympic Games or the World Cup is generally expected to have a positive impact on a country's image and to promote tourism. Consequently countries often compete to host such an event (Heslop, Nadeau, \& O'Reilly, 2010). In the case of Brazil, our context here, prior work on its relative appeal as a tourism destination (Pike, 2016) and in general (Guina \& Giraldi, 2012; Mariutti, \& Tench, 2016) provides a mixed picture, emphasising the need for the country to improve its external image. On the one hand, the image of Brazil was often viewed positively because of features such as Carnival, natural beauty, football and music (Mariutti, Giraldi \& Crescitelli, 2013). On the other hand, Brazil's image has included negative connotations, such as crime, violence and poverty (Buarque, 2015)

In 2007 Brazil emerged as the only contender to host the 2014 FIFA World Cup. Hosting the event and the 2016 Olympic Games that followed were part of a wider strategy of sports diplomacy to enhance Brazil's reputation, symbolizing the country's rise on the international stage and its emerging role in world affairs (Soares e Castro, 2013). Expectations preceding the event were high. A study by Ernst \& Young predicted an increase of 2.98 million tourists as a direct result of the World Cup. Embratur, the Brazilian Tourism Board, expected to see revenue from international tourism increase to US\$ 18 billion by 2020 from US\$ 5.9 billion in 2010 (Jainchill, 2013). However Brazil's image internationally fell between 2013 and 2015 both in 
absolute terms and when compared with the mean scores for the G8 nations (RI, 2017).

International tourist numbers had been rising steadily between 2010 and 2014 but fell back between 2014 and 2015 (by 1.93\%) and grew relatively slowly thereafter, 4.3\% between 2015 and 2016 compared with South America in total at 6.6\% (WTTC, 2017). This was despite Brazil's hosting the Olympic Games in 2016. Total revenues from tourism peaked in 2014 and fell back to $\$ 6.02$ billion in 2016 . Such disappointing results would be blamed on negative media influencing international public opinion (Buarque, 2015; Mitra, 2015). Our own work would show, however, that such effects were mixed, as attitudes among some individuals improved, even though, on average, they declined. Our aim here is to understand and explain why.

As Getz and Page (2016) note, our understanding of the effectiveness of events is far from adequate to enable us to predict the outcomes of any one planned event. Given the high cost of holding larger events and the potential risks to a country's image represented by Brazil's sponsorship of the World Cup we need to move closer to such a goal. Our paper focusses on the change in image and tourism intentions among potential tourists towards Brazil as a destination associated with its hosting the World Cup in 2014. First we discuss the background to the event and existing work on similar uses of such 'soft power' defined as the ability to affect others to obtain the outcomes one wants through attraction rather than coercion or payment (Nye, 1990). We then propose a number of hypotheses developed from existing work and theory predicting the effects of sports sponsorship on the host country's image and towards tourism intentions and, in particular, the moderating effects that can be expected. Our empirical work follows, two surveys among the same residents of three countries, Colombia, 
Austria and Peru, one either side of the event $(n=207)$. This approach, compared with cross sectional or pre and post sampling allows an investigation of the effects of a major event at the level of the individual. Our main objective is to contribute to the literature aimed at understanding the influence of hosting large scale sporting events on country image and tourism and specifically when and why such outcomes can be mixed. In particular we will show how a number of moderating factors specific to the individual, (including an Open to Experience Personality and involvement in the event) can create positive or negative effects on the individual's tourism intentions to a country hosting a major sporting event. Tourism intention refers to the willingness to travelling to a destination, in our case Brazil (see also Ahn, Ekinci \& Li, 2013; Baker \& Crompton, 2000).

\subsection{The Brazilian Context}

The Brazilian government estimated that it would cost US\$13.35 billion to host the World Cup in 2014, with the majority of these funds devoted to improvements in public transportation (31.3\%), stadia (31.2\%) and airports (24.5\%), with an estimated $85 \%$ coming from federal and state budgets. Additionally, Brazil would spend US\$ 40 million on a global advertising campaign, with the objective of broadening Brazil's international image from that of "a country with soccer and samba" (Jainchill, 2013). Our focus is on changes in image and tourism intentions, but Brazil's image as an exporting country was also at issue (Guina \& Giraldi, 2015; Lopes, Giraldi, \& Aguiar, 2014; Bachion. \& Zuca de Souza, 2016).

Buarque (2015) analysed media comment about Brazil associated with the country's hosting both the 1950 and 2014 World Cup competitions. He concluded that there was an increase in 
the visibility of Brazil as a result of both events, but that there was a change in the framing used to describe Brazil by the media, from the economy and culture following 1950 to politics following 2014, and a change in the tone of media comment, from positive to negative. Hosting a sporting event can indeed have negative, as well as positive, effects on public attitudes (Chalip, Green, \& Hill, 2003). Brazil lost in the semi-finals in 2014 to Germany 7-1, the worst defeat in the country's sporting history, damaging its prestige as a football nation (Chari, 2015). But while football made headlines and dominated sports coverage, many of the 16,746 journalists accredited to the event took the opportunity to focus upon other, less positive, aspects of the host country. Examples of negative media both inside and outside of Brazil had emerged almost as soon as the country were awarded the event by FIFA in 2007. At issue was whether the decision to bid for the hosting rights for the 2014 FIFA World Cup was ethical and morally justifiable in light of the pressing need for extensive public investment of more direct benefit to the population (Mitra, 2015).

However, according to FIFA, the World cup in 2014 was a sporting success, and they labelled it as 'the most seen and the most talked about sporting event in history' (FIFA, 2015). The total attendance for the 64 matches was 3,429,873, the highest recorded at any World Cup since USA 1994. 5,154,386 people had attended FIFA Fan Fests, with Rio de Janeiro's spectacular Copacabana site attracting 937,330 - the highest number in any individual city. The average crowd at matches of 53,592 was also the highest in two decades. Tax revenues from the event totalled $\$ 7.2$ billion (FIFA, 2015). The head of Brazil's tourism appeared pleased, as the event generated large numbers of foreign tourists and little disruption (Neto, 2014). Adidas, a major 
sponsor, similarly appeared to be satisfied with their investment and association with the event (Adidas, 2014).

\subsection{Theory and Hypotheses}

\subsection{The Effects of hosting a Major Event}

A major event can improve both awareness and image of the host country (Kim \& Morrison, 2005). There is a significant relationship between a country's image and intent to visit the country (Gibson, Qi, \& Zhang, 2008) and to recommend to others to do the same (Choi, Tkachenko, \& Sil, 2011; Stylidis, Shani, \& Belhassen, 2017). Some major events such as the World Cup and the Olympic Games have been categorised as mega events, defined as occasions of a fixed duration that attract (1) a large number of visitors, (2) have a large mediated reach, (3) come with large costs, and (4) have large impacts on the built environment and the population (Müller, 2015: 634). Their effects can be substantial and long-lasting (Fourie \& Santana-Gallego, 2011). Not surprisingly, governments, particularly those of developing countries, see such events as opportunities to change their nation's brand imagery (Heslop, Nadeau, \& O'Reilly, 2010). However, and as we have noted, this particular event attracted negative as well as positive reactions (Buarque, 2015). One additional benefit from hosting a major sporting event is through image transfer (Gwinner \& Eaton, 1999) here from FIFA and the FIFA World Cup to Brazil. FIFA would have reputation and image problems of its own, but these emerged only after 2014 and our survey work. 
Much research into nation branding has adopted the perspective of the country of origin (COO). The COO effect is similar to that of a stereotype, as individuals (here in another country) generalise any cues (such as the perceived industrial development of the country) to influence their perceptions of any outputs from the country. Actual experience with the country then modifies the stereotype over time to change it from a halo effect to a summary construct (Jaffe \& Nebenzahl, 2006). Changing any stereotype can be difficult but can be facilitated by involving individuals in a different discourse (Van Langenhove \& Harré, 1995) allowing them to change their attitudes towards, in this case, a country. There is empirical support for the idea to explain how individuals can update their image of a country and its services (Gurhan-Canli \& Maheswaran, 2000).

An allied perspective to that of the $\mathrm{COO}$ is to consider the nation as a brand with its own (nation) brand personality (NBP). The idea has been used to predict attitude and behavior towards a country (d'Astous \& Boujbel, 2007; Rojas-Mendez \& Papadopoulos, 2012; Kim, Shim, \& Dinnie, 2013; Rojas-Mendez, Murphy, \& Papadopoulos, 2013a; Song \& Sung, 2013). NBP has been defined as "a set of positive and/or negative human personality traits comprising specific dimensions that internal and external audiences associate with a country name, based on previous experiences and perceptions as a consequence of the actions, intentions, and opinions of that country's government, companies and institutions, and society at large" (Rojas-Mendez, Murphy \& Papadopoulos, 2013: 1029). Country imagery can also be measured using more cognitive measures, such as that from the Reputation Institute, which asks respondents, for example, whether the country values education, whether the people are friendly and 
welcoming and whether its government operates efficiently $(R I, 2017)$. Here we use both types of measure together with tourism intentions.

Most prior work assumes a positive relationship between hosting a major sports event and country image (Herz \& Arnegger, 2017) and this relationship may even have become a naïve theory. Few acknowledge that positive outcomes may be mitigated by, for example in our context, the media questioning whether the ordinary Brazilian actually benefited (Butler \& Aicher, 2015). Congruence theory has been used to explain how individuals process (sometimes conflicting) information (Osgood \& Tannenbaum, 1955). For example a spokesperson's image should be congruent with that of the product (Kamins \& Gupta, 1994) or a retailer's website congruent with that of its high street stores (Wang, Beatty, \& Mothersbaugh, 2009) to have a positive effect on image. In the context of country image experiences with products from a country may not influence that country's image if the product is not congruent with that country (Lee, Lockshin, \& Greenacre, 2016). For example perfume might be seen as a product congruent with the image of France, while whisky may not. Here a football competition might be expected to be congruent with the image of Brazil but at the same time images of social deprivation are likely to be seen as incongruent with the cost of hosting a global football competition, calling into question the country's governance, and likely to influence country image (Zavattaro \& Fay, 2019).

When faced with a number of signals or cues from the same entity relevant to an evaluation an individual needs to make, information integration theory argues that the consequences of 
different information are averaged (Anderson, 1971) by simple or weighted averaging or by the two signals interacting (Anderson, 2013). The weights assigned to different cues by individuals are likely to vary, leading to a range of outcomes.

A major cultural event and the increased media coverage associated with it, should provide a context whereby residents of other nations can evolve a more positive image of the host nation and behavioral intention including tourism. On the other hand any associated negative rhetoric of the kind identified by Buarque (2015) might provoke an opposing effect. Consequently as the overall effects on the individual can be expected to be either positive, negative or neutral, our baseline hypothesis is then only that a relationship can exist between hosting an event and the image of the host nation, such that:

\section{H1: The image of a host nation will change following a mega-event either positively or} negatively.

Because the World Cup would allow individuals to update their perceptions of Brazil (GurhanCanli \& Maheswaran, 2000) and the image of a nation influences those towards its outputs including tourism (Gibson et al., 2008; Choi, et al., 2011; Stylidis, et al., 2017), we can expect any positive/negative change in the image of a nation to produce a positive/negative changes in tourism intentions, hence:

\section{H2: A positive/negative change in country image will cause a positive/negative change in tourism intentions to that country}




\subsection{Media Coverage}

One way country image is formed and changed is through media exposure (Baloglu \& McCleary, 1999; Li \& Kaplanidou, 2013) and the media have been shown to affect how people think about other nations (Wanta, Golan \& Lee, 2004). Consequently media coverage of a major international sports event is integral to any image development for the host country (Getz \& Fairley, 2003). Gaining media publicity is also beneficial because it is seen as communication independent of the event's sponsor (i.e. the country) (Balasubramanian, 1994).

Each time people read a news report about the country or mega event, they form or update a mental representation they have about the country and/or the event (van Dijk, 1996). The media influence which views are dominant in society and impact upon what people say or not in public. If readers/viewers sense their own views are not widely held, they remain silent to avoid social isolation. Consequently dominant views gain more ground (Noelle-Neumann, 1993).

731,808 articles were written about the World Cup by the global media between April 1st, 2014 and July 15th, 2014, but there were five times as many more negative articles than positive articles about Brazil (Moreover, 2014). Negative publicity can impact any type of organisation (Tybout et al. 1981; Wyatt \& Badger, 1984; Huang \& Chen, 2006; Goldenberg et al., 2007) and negative news is more influential than positive news (Kroloff, 1988). Media exposure plays a more important role in forming/altering country images amongst people who follow any mega event as opposed to those who do not (Li \& Kaplanidou, 2013). 
In summary, if media comment about a country surrounding a major event is seen as positive by the individual, this will enhance their perception of the country and enhance the influence of the event itself, while if it is negative it will reduce any positive effect from the event itself. Consequently we can expect a moderating influence from the valence of the media experienced by the individual. Hence:

H3: Any change either side of hosting a major event in (a) country image and (b) tourism intentions will be moderated by the valence of media content.

\subsection{Involvement}

Involvement has been found to influence attitudes and to predict behaviour (Dimanche, 1990) and to moderate various facets of consumer behaviour (Dholakia, 2001). Here we would expect that an involvement in football might moderate any change in how Brazil was seen due to hosting the World Cup as those more involved in football would be more likely to be influenced by the sports event and less likely to be influenced by any concomitant negative comments on how the country is run. Similarly involvement in the event itself (e.g. viewing the closing ceremony) can be expected to have a similar effect. Hence:

H4: The change either side of hosting a major sports event in (a) country image and (b) tourism intentions will be moderated by the involvement of the individual in the sport and in the event itself 


\subsection{The Personality of the Individual}

Someone's personality can often explain their attitudes and behaviours. In the context of tourism one dimension, Open to Experience (OTE), can be expected to be particularly influential, as 'providing experiences is a central concern in the development of Tourism' (Selstad, 2007: 19). OTE has been shown to moderate relationships in a tourism context, between the experience and satisfaction (Bujisic, Bilgihan, \& Smith, 2015). Those scoring high on this personality dimension tend to be more liberal politically (McCrae, 1996), and to be more open minded on issues such as diversity in society (Jost, 2006). They tend to reject elitism and to be less prejudiced (Sibley \& Duckitt, 2008). Of specific relevance to our context is the association of OTE with news consumption of a political nature (Gerber et al., 2011) suggesting that those with more open personalities would be more affected by any negative media comment associated with the event, but not that related to the football competition itself. Hence, in our context:

H5: The change either side of hosting a major sports event in tourism intentions will be moderated by respondent personality, specifically their Openness to Experience

\subsection{Control variables}

As football is a more male than female oriented sport there could be gender effects on the relevance of individual factors when explaining outcomes. We might also expect age effects as age has been shown to influence attitudes towards tourism (Han, Hsu, \& Lee, 2009). We have already identified involvement in the sport being hosted (in this case football) in proposing our 
hypotheses but we were also conscious of the possibility that attitudes might be shaped by the country any respondents came from and for two reasons. First whether a country was represented in the 2014 event could be important, and second how easy it might be to consider tourism to Brazil, particularly how geographically close their own country might be. Consequently we decided to measure the effects of the World Cup on Brazil's image and tourism intentions in three countries, two adjacent to Brazil, Colombia and Peru, the former having also reached the World Cup finals, and Austria, who had not reached the finals and who is not geographically close to Brazil. We also included measures of respondent education, and any prior links with Brazil.

\subsection{Methods and Measures}

Most prior work on the effects of country brand imagery has adopted a cross-sectional methodology. More recently researchers have adopted a longitudinal approach, measuring location image either side of an event. However this ideally involves interviewing the same individuals at both time points (e.g. Sun \& Paswan, 2012; Herz \& Arnegger, 2017), a possible explanation for the lack of such studies (Lee et al., 2014). Here the same citizens of Colombia (91), Austria (50) and Peru (66) were interviewed one month before and again one month after the 2014 World Cup. This allows us to test our hypotheses directly and by doing so examine the effects of the event at the level of the individual. Respondents to the first survey who agreed were sent a further questionnaire and their responses matched to their initial data not only by matching the email address but also by ensuring that the demographic information was the 
same on both questionnaires. The survey was conducted online in Spanish or German using a convenience sample in all cases.

There are options for measuring country image which divide into two broad groups, cognitive and affective. In the former respondents are asked, for example, about how democratic they believe the country to be or about its standard of living (see for example Giraldi et al., 2017). More affective measures include that of the NBP and we used measures of both types. Our more cognitive measure was of 'overall attitude' from Rojas-Mendez, Murphy \& Papadopoulos (2013). For the affective measures, and following Davies et al. (2018) we focused on three 'core' dimensions of NBP, Warmth (e.g. trustworthy and friendly), Competence (e.g. skilful and enterprising), and Status (e.g. sophisticated and elegant). Our measurement items for these and for tourism intentions were taken from Rojas-Mendez, Papadopoulos \& Murphy (2013). In addition to asking for demographic information, such as age, gender and education, we included measures of respondent personality (Gosling, Rentfrow, \& Swann Jr., 2003) and attitude towards football (Beasley \& Shank, 1998). We also included questions about frequency of watching football. The second questionnaire (sent after the event) contained an additional question designed to assess the valence of news the respondent had read about the World Cup. Each respondent was exposed to a randomly ordered list of the same questions. All measures and their reliabilities are given in the Appendix.

\subsection{Findings}

\subsection{Change in Attitudes either side of the World Cup}


The average of our cognitive measure (calculated as the mean for all respondents) fell post event and significantly so: Overall Attitude $\left(\right.$ Mean $_{1}=3.30$ Mean $\left._{2}=3.16, p<.001\right)$. The pre and post event measures for individual respondents correlated significantly (Overall Attitude CC $=0.78, p<.001$ ) but not perfectly. The mean scores for the three dimensions of NBP also declined but only in one case significantly so: Warmth $_{1}=3.05$, Warmth $_{2}=3.04(p=.83)$, Competence $_{1}=3.76$ Competence $_{2}=3.61(p=.028)$ and Status ${ }_{1}=3.03$ Status $_{2}=2.95(p=.10)$. Again the measures either side of the event correlated significantly but not perfectly (Warmth CC = $.53, p<.001$, Competence $C C=.67, p=<.001$ and Status $C C=.55 p<.001)$.

$\mathrm{H} 1$ is supported by our data, hosting the World Cup in 2014 was associated with a change in attitude towards Brazil which had declined, and significantly so on two of our four measures, a finding compatible with the only other study we could find, RI (2017), but which had used different samples either side of the event.

\subsection{Changes in Tourism Intentions}

Tourism intentions had fallen on average $\left(\right.$ Mean $_{1}=3.69$, Mean $\left._{2}=3.50, p<.001\right)$ and while the measure correlated significantly for individuals either side of the event $(C C=0.77, p<.001)$ the correlation was not perfect. Our second hypothesis proposed that these changes would depend upon the changes in Brazil's image. But we could not be sure whether the differences would be better explained by changes in the more cognitive measure or the more affective measure of brand personality. We used multiple regression to test this, Table 1. The model gave an adjusted $R^{2}$ of .15 $(p<.001)$, which is deemed adequate/moderate for studies in behavioral 
sciences (Cohen, 1988; Falk and Miller, 1992). Using stepwise regression produced the same overall finding, that the change in tourism intentions was best understood by the change in overall attitude towards Brazil. $\mathrm{H} 2$ is supported.

\begin{tabular}{|l|l|l|l|}
\hline Variable & Beta & $\mathrm{t}$ & Sig \\
\hline Constant & & 2.72 & .007 \\
\hline Change in Overall Attitude & .378 & 5.66 & .000 \\
\hline Change in Warmth & .025 & .340 & .734 \\
\hline Change in Competence & -.102 & -1.37 & .172 \\
\hline Change in Status & .038 & .533 & .595 \\
\hline
\end{tabular}

Table 1: Regression to Predict Change in Tourism Intentions ( $\mathbf{n = 2 0 7 )}$

When the change in more cognitive attitude was removed from the regression, the model became non-significant $(p=.068)$. However when stepwise regression was used, the model was significant $\left(p=.012, R^{2}=.030\right)$ but only brand competence was retained (and it was also the only affective measure to decline significantly). All individual measures of NBP however correlated significantly $(p<.001)$ both pre and post event with tourism intentions.

We now turn to the issue of why some respondents reported improvements in country imagery and tourism intentions while others became less positive or remained the same.

For the travel measure 33 respondents (15.9\%) returned the same score pre and post-event, 110 (53.2\%) reported a reduced score and 64 (20.9\%) a higher score. For the overall attitude measure $44(21.3 \%)$ returned the same score, $112(49.3 \%)$ a reduced score and $61(29.5 \%)$ a 
higher score. The mean Warmth measures were almost identical pre and post-event but this hid the fact that only 75(26.2\%) reported lower Warmth, 85 (41.1\%) reported higher figures and $47(22.7 \%)$ the same. Only a minority scored Brazil substantially lower post-event. Such differences suggest that there might be a third factor influencing and therefore explaining the change in the evaluations.

In the following sections we tested the explanation that one or more factors were moderating (creating more positive or more negative change in) the relationship between pre and post measures, first for Warmth.

\subsection{News Valence and Warmth Evaluations}

We were particularly interested in understanding why there was no significant difference in the brand image of Brazil for Warmth either side of the event. This is surprising as pre and post Warmth measures correlated significantly with both Overall attitudes and Tourism intentions. Warmth (which contains the measurement items trustworthy and honest) has been found to be relatively influential in predicting satisfaction in prior work (Davies et al., 2018). Part of the explanation came from the moderating effect of news valence. Our measure of respondent perception of media coverage they had seen was a single item using a 7 point scale ranging from $1=$ very negative to $7=$ very positive in the second survey. We used the Process macro in SPSS to test for moderation (Hayes, 2017). Moderation is demonstrated in the relationship between two variables by a third variable when the interaction term between the independent variable and the third variable is significant in predicting the dependent variable. The 
consequences are that the relationship between the original two variables is shown to depend on the value of the third variable. The measure of media coverage proved to be a significant moderator of the change in Brazil's brand personality for Warmth (Table 2 and Figure 1). The adjusted $R^{2}$ figure for the equation was .34 and it was significant $(p<.001)$.

\begin{tabular}{|l|l|l|l|l|}
\hline Term & Coefficient & s.e. & t & p \\
\hline Constant & -.300 & .45 & -.65 & .518 \\
\hline Warmth pre-event & 1.03 & .15 & 7.06 & $<.0001$ \\
\hline News Valence & .492 & .13 & 3.89 & .0001 \\
\hline Interaction News x Warmth & -.141 & .040 & -3.51 & .0006 \\
\hline
\end{tabular}

Table 2 Moderation effects by News Valence when predicting Warmth post event from Warmth pre-event $(n=207)$

Figure 1 shows the relationship between Warmth evaluations pre-event and post-event for different values of the news measure. The higher the value of news valence in Figure 1, the more positive had been the reported news media content regarding Brazil. Those exposed to more negatively valenced reports who evaluated Brazil's Warmth low pre-event did not change their views while those in the same group who evaluated Brazil high for Warmth pre-event reported much lower values post event. In contrast, those who felt they had been exposed to more positive media coverage reported higher evaluations post event if they had a low opinion pre-event, but lower values if they had a higher opinion pre-event. While, on average, there was no change among the 207 respondents' views of Warmth, the more complex but detailed picture from considering the moderating influence of news valence is more consistent with 
what can be expected from prior work and theory; news valence influences NBP. H3 is supported

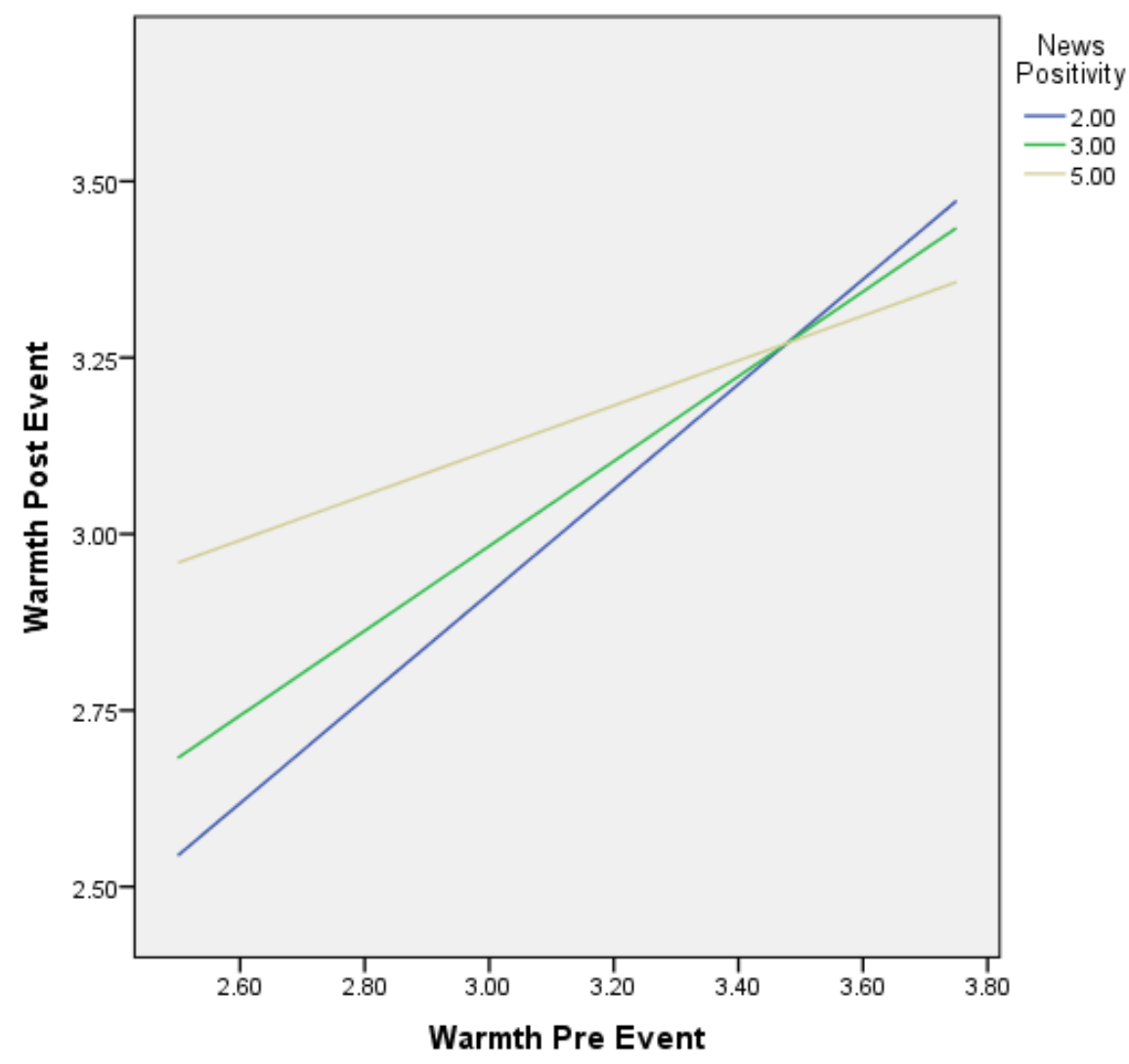

Figure 1 Contrasting Changes in Warmth Evaluations for Different Valence of News Exposure

There was a similar but not so significant effect by news valence on changes in perceived Competence but not for Status, overall attitude or tourism intentions.

\subsection{News Search and Change in Overall Attitude}

Whether respondents had searched for news about Brazil before the World Cup (a measure of their involvement in the country and the event) proved to be a moderator between pre and 
post overall attitude to the country. The measure was a single item, scaled from $1=$ never to $5=$ frequently. The contribution of news search to explaining differences in the change in overall attitude towards Brazil is illustrated in Table 3 and Figure 2. Those who searched more for news about Brazil and who had a poorer attitude towards Brazil before the World Cup reported more positive attitudes after the event. For most others their overall attitudes declined. $\mathrm{H} 4$ is supported.

\begin{tabular}{|l|l|l|l|l|}
\hline Term & \multicolumn{1}{|c|}{ Coefficient } & \multicolumn{1}{c|}{ s.e. } & \multicolumn{1}{c|}{$\mathrm{t}$} & \multicolumn{1}{c|}{$\mathrm{p}$} \\
\hline Constant & .0153 & .269 & .0569 & .955 \\
\hline Attitude to Brazil Pre-event & .874 & .0820 & 10.66 & $<.0001$ \\
\hline $\begin{array}{l}\text { News searching about Brazil pre- } \\
\text { event }\end{array}$ & .518 & .1260 & 4.11 & .0001 \\
\hline Interaction & -.114 & .0349 & -3.27 & .0013 \\
\hline
\end{tabular}

Table 3 Moderation effects on change in overall attitude towards Brazil $(n=207)$

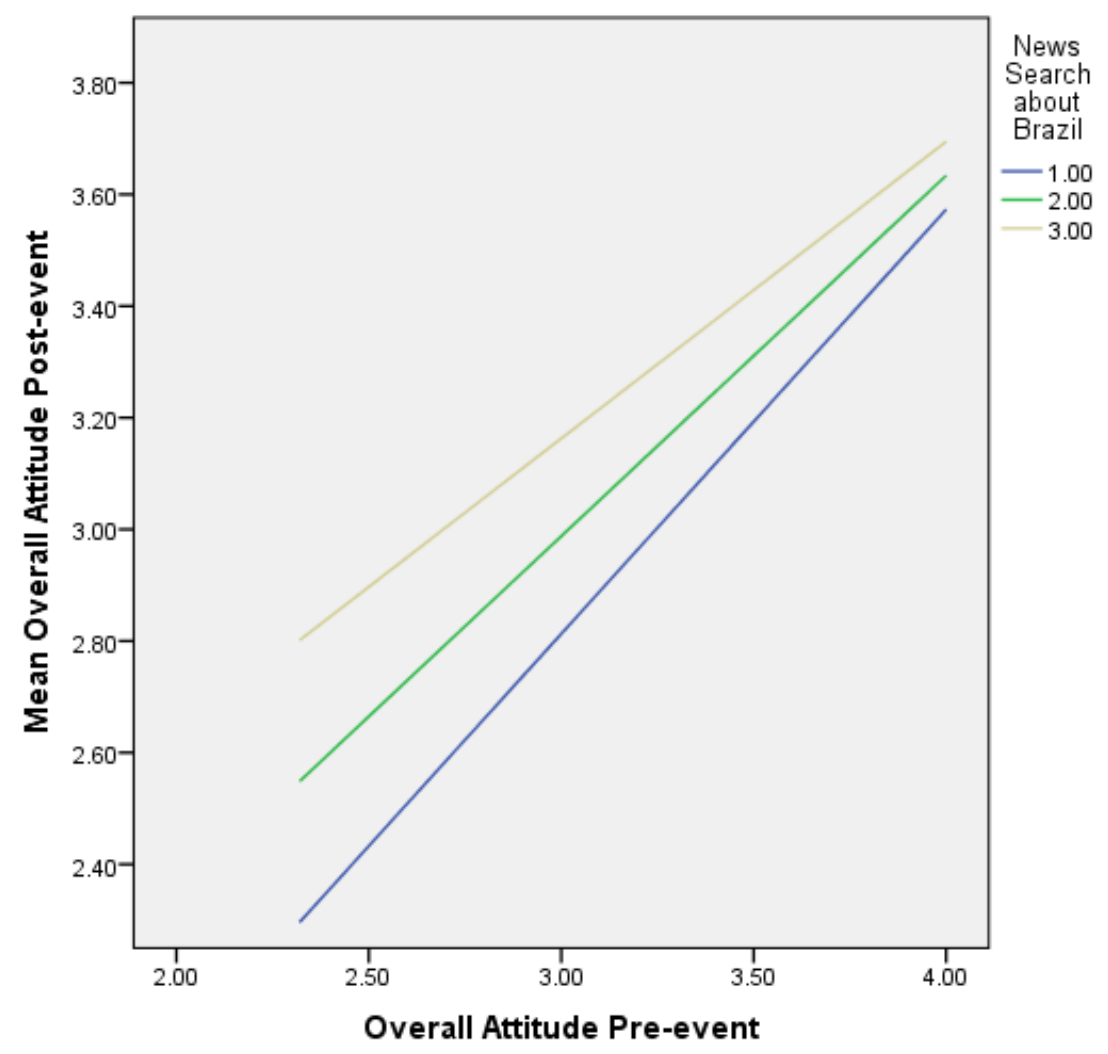

Figure 2 The Influence of News Searching about Brazil on pre and post overall attitudes. 


\subsection{Watching the Closing Ceremony and Warmth Evaluations}

The final of the World Cup attracted a global audience of 570 million. It was preceded by the closing ceremony which featured, among others, international pop star Shakira. We asked respondents if they had watched the closing ceremony using a three point scale from $1=$ yes totally to $3=$ No. This measure also moderated the relationship between pre and post Warmth, Table 4 and Figure 3. Note that the moderating effect of the influence of Warmth pre-event on Warmth post event is substantial (it had no direct significant effect on Warmth post event in the model). The model is significant $(p<.001)$ and yielded an adjusted $R^{2}$ of .31 .

\begin{tabular}{|l|l|l|l|l|}
\hline Term & Coefficient & s.e. & t & p \\
\hline Constant & 3.15 & .653 & 4.82 & $<.001$ \\
\hline Warmth pre-event & -.0205 & .203 & -.101 & .919 \\
\hline Watched Closing Ceremony & -.773 & .258 & -3.00 & .003 \\
\hline Interaction Term & .251 & .082 & 3.08 & .0024 \\
\hline
\end{tabular}

Table 4 Moderation effects by watching the closing ceremony when predicting Warmth post event from Warmth pre-event $(n=207)$

Those who watched all of the closing ceremony (denoted by 1 in the key in Figure 3) and who had a relatively low perception of Brazil measured by Warmth, increased their perception post event, while those who began with a high perception of Warmth returned much lower evaluations post-event. Those who did not watch the closing ceremony reported lower evaluations post-event. 


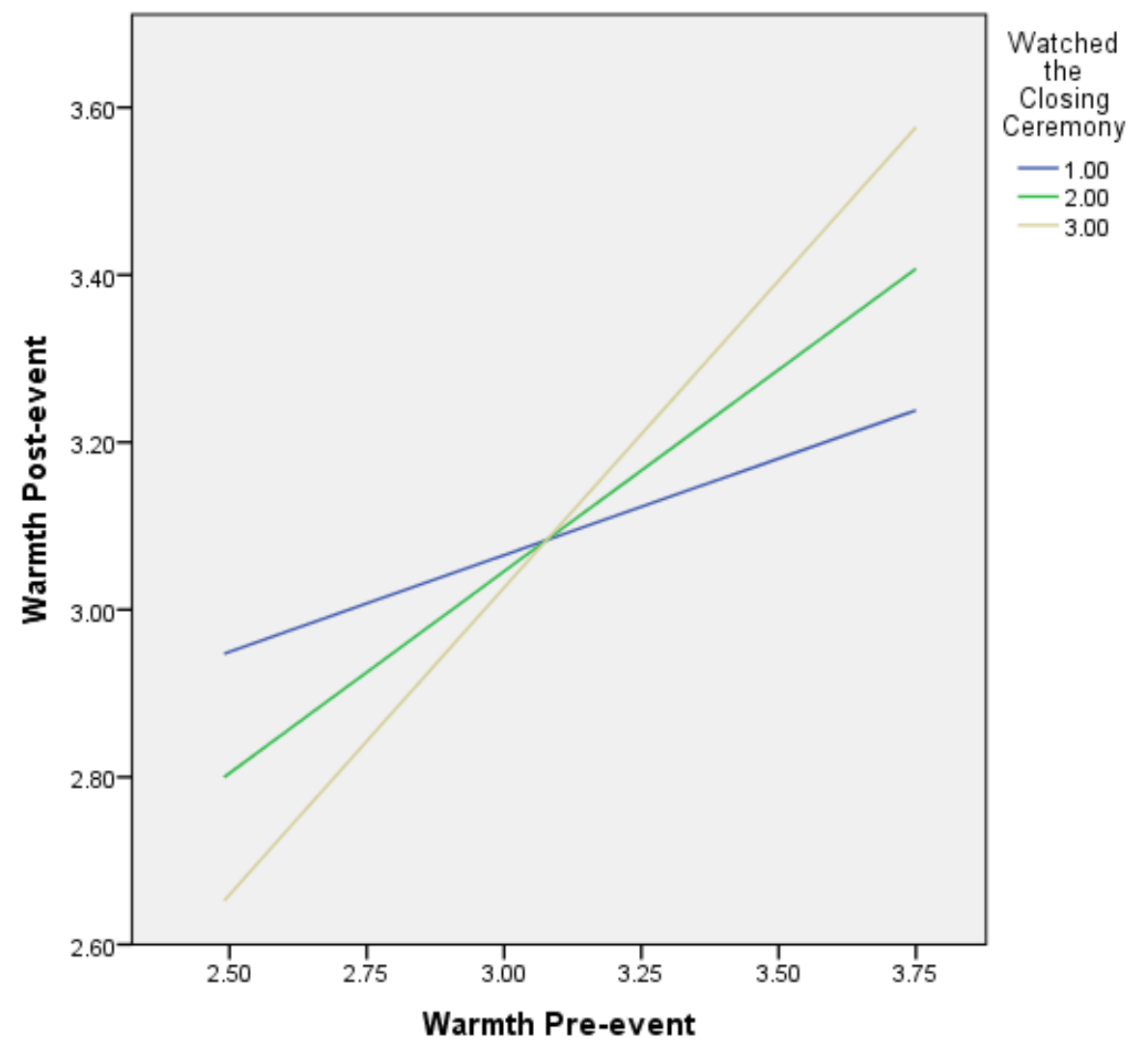

Figure 3 Contrasting Changes in Warmth Evaluations for Different Exposure to the Closing Ceremony

We also tested whether the two moderating influences (of news valence and of watching the ceremony) were independent of each other by introducing both into a moderation model (Model 2 in the Hayes macro). Both influences remained significant. H4 is supported in the context of an involvement in the major event. We also tested the possible moderating effects of an involvement in football and of the number of World Cup games respondents reported watching. Neither proved significant and $\mathbf{H} 4$ was not supported in the context of involvement in football. 


\subsection{Tourism Intentions and Respondent OTE}

We expected that a respondent's personality might help explain differing changes in tourism intentions and hypothesised that Openness to Experience would be the most likely aspect of personality to be relevant. It proved significant as a moderator of the relationship between pre-event and post-event tourism intentions, Table 5.

\begin{tabular}{|l|l|l|l|l|}
\hline Term & Coefficient & s.e. & t & $\mathbf{p}$ \\
\hline Constant & .494 & .18 & 2.75 & .007 \\
\hline Tourism Intentions pre-event & .832 & .048 & 17.5 & $<.0001$ \\
\hline OTE & -.293 & .0994 & -2.95 & .0035 \\
\hline Interaction Tourism Intention x OTE & .0859 & .0263 & 3.26 & .0013 \\
\hline
\end{tabular}

Table 5 Moderation effects by Respondent OTE when predicting Tourism Intentions post event from Tourism Intentions pre-event $(n=207)$

The adjusted $R^{2}$ figure for the equation was .62 and it was significant $(p<.0001)$.

As indicated by Figure 4, higher levels of respondent OTE are associated with less of a reduction

in tourism intentions than among those with lower OTE. Put another way OTE helps explain the high variance in the post event among those who had expressed a higher likelihood of visiting Brazil pre-event. Those with a high OTE were more likely to retain their interest in visiting Brazil. No other dimension of human personality gave a moderating effect on change in tourism intentions. $\mathbf{H} \mathbf{5}$ is supported 


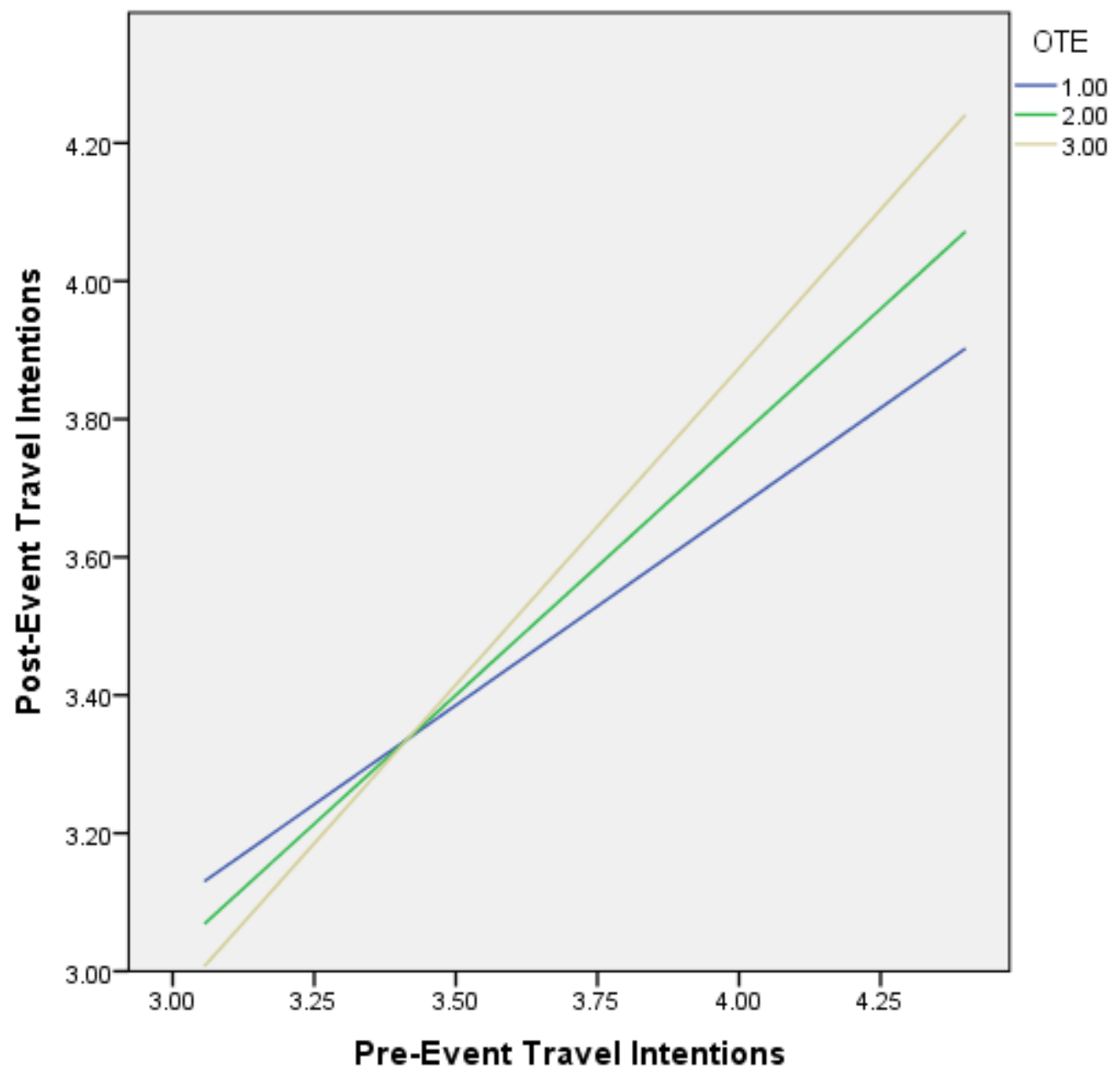

Figure 4 Contrasting Changes in Travel Intentions at Different levels of Respondent OTE

\subsection{Sensitivity Analysis}

Control variables (age, gender, education, country of residence, prior connections with Brazil) were included in each of the preceding moderation analyses, but the overall pictures provided did not change, supporting the findings as being generalizable. 


\subsection{Discussion}

When we began our research we did not expect the World Cup would have an associated negative effect on attitudes towards the host nation. But even before we had analysed our data, it was clear that media comment not directly associated with the event or a greater understanding of social issues might have reduced or countered any positive impact from the event itself. Our first finding, that the event is associated with a fall in overall imagery and tourism intentions could not have been expected from the literature on event sponsorship (e.g. Gwinner \& Eaton, 1999) but it is compatible with the literature specific to the 2014 World Cup (Buarque, 2015; RI, 2017) and to the idea that hosting the World Cup as a market signal might be seen as incongruent with being told about the country's social issues (Osgood \& Tannenbaum, 1955; Lee, Lockshin, \& Greenacre, 2016). However our data also showed that while there had been an overall reduction in some measures as assessed by average figures, those of a substantial minority had actually increased. This supports the idea of individuals using weighted averaging of multiple sources of information (Anderson, 1971; Anderson, 2013) when reaching an overall evaluation.

Our second hypothesis tested the link between a change in overall image for the country and a change in tourism intentions. Confirming some prior work on sporting events but which relied upon cross sectional or longitudinal studies among different respondent groups (Gibson et al., 2008; Choi et al., 2011; Stylidis et al., 2017; Fourie \& Santana-Gallego, 2011) that the two are positively associated, our work, among the same respondents pre and post-event, shows a clear link between a change in overall image and a change in tourism intentions. However the link is 
better explained in our work by a more cognitive view of country image than by measures of NBP. Among the latter measures perceived Competence emerged as the most relevant.

Our third hypothesis tested the idea that negative news coverage might explain such complex changes in Brazil's Image and individual tourism intentions. While the hypothesis is supported by prior work (Li \& Kaplanidou, 2013; Buarque, 2015) our study shows that news valence was only important in explaining changes in perceived Warmth and did not explain changes in tourism intentions directly.

As we expected, the World Cup had a more positive effect on respondents who were more involved. But somewhat surprisingly the effect was not driven by an involvement in football or by how involved individuals watched the World Cup matches, but by an involvement in the broader event, such as the closing ceremony or by searching for news items about the country. Furthermore the positive effect was only among those who had a held a relatively low attitude towards Brazil before the World Cup. Hosting the event was then successful when reaching this group, but only if they were involved.

Our final hypothesis concerned the influence of respondent personality on changes in attitude. As expected an OTE personality, with its association with tourism (Selstad, 2007; (Bujisic et al., 2015) and politics (McCrae, 1996; Jost, 2006; Sibley \& Duckitt, 2008; Gerber et al., 2011) proved useful in understanding changes in tourism intentions. Further no other dimension of human personality proved to be a significant moderator. 
Table 6 summarises the evidence from our work that is statistically significant against each hypothesis.

\begin{tabular}{|l|l|}
\hline \multicolumn{1}{|c|}{ Hypothesis } & \multicolumn{1}{|c|}{ Evidence } \\
\hline $\begin{array}{l}\text { H1: The image of a host nation will } \\
\text { change following a mega-event either } \\
\text { positively or negatively }\end{array}$ & $\begin{array}{l}\text { Supported. Significant declines were found } \\
\text { for overall attitude and for NBP but both } \\
\text { positive and negative changes at the level } \\
\text { of the individual. }\end{array}$ \\
\hline $\begin{array}{l}\text { H2: A positive/negative change in a } \\
\text { country's image will cause a } \\
\text { positive/negative change in tourism } \\
\text { intentions to that country }\end{array}$ & $\begin{array}{l}\text { Supported. Changes in tourism intentions } \\
\text { were explained by changes in overall } \\
\text { attitude towards the host country, but } \\
\text { more effectively by changes in cognitive } \\
\text { attitude }\end{array}$ \\
\hline $\begin{array}{l}\text { H3: Any change either side of hosting a } \\
\text { major event in (a) country image and (b) } \\
\text { tourism intentions will be moderated by } \\
\text { the valence of media content }\end{array}$ & $\begin{array}{l}\text { Supported but only for the NBP dimension } \\
\text { of Warmth. }\end{array}$ \\
\hline $\begin{array}{l}\text { H4: The change either side of hosting a } \\
\text { major sports event in (a) country image } \\
\text { and (b) tourism intentions will be } \\
\text { moderated by the involvement of the } \\
\text { individual in the sport and in the event } \\
\text { itself }\end{array}$ & $\begin{array}{l}\text { Not supported by any of our involvement } \\
\text { measures for sport but supported by two } \\
\text { measures of involvement in the event, } \\
\text { searching on-line for news about Brazil and } \\
\text { watching the closing ceremony. }\end{array}$ \\
\hline $\begin{array}{l}\text { H5: The change either side of hosting a } \\
\text { major sports event in tourism intentions } \\
\text { will be moderated by respondent } \\
\text { personality, specifically their Openness } \\
\text { to Experience }\end{array}$ & \begin{tabular}{l} 
Supported \\
\hline
\end{tabular}
\end{tabular}

Table 6 Summary of Hypotheses

A main contribution from our work is to explain how and why individuals can differ in their reaction to the same attempt to use soft power to influence the image of a country and tourism intentions. In general those who held a relatively poor attitude pre-event were far more likely to be positively influenced. Apart from those with a high OTE personality, attitudes among 
those previously holding a more positive attitude reported a reduction in attitude following the event. This had the effect of making attitudes more similar post-event, as the standard deviations of all attitude measures, other than Warmth, decreased. For tourism intentions the change in variance pre and post-event was significant (Levene test, $F=4.03, p=.045$ ).

The fall in tourism intentions as measured by the mean figure disguised the reality that those most likely to visit Brazil reduced their intentions far more than the mean implies. Those increasing their travel intentions were the least likely to visit pre-event and remained the least likely visitors post-event. Adding to this the fact that Brazil's unexpected failure to progress to the World Cup final meant that more visitors arrived from nearby Argentina, whose team did progress (Baumann \& Matheson, 2018), emphasises the negative effect of the event on Brazil's tourism.

There is an implied assumption in the literature that countries hosting major events can expect a positive change in their image and fortunes. However the cost of such promotion is high in monetary terms and in social cost to the citizens whose lives might be disrupted by holding the event or who might believe that the money would have been better spent elsewhere. Press reports emphasised that Brazil had spent $\$ 15$ billion in hosting the World Cup, while FIFA had pocketed over $\$ 2$ billion. Social unrest became an unwelcome memory and legacy of what was, as an event, a sporting success (Korstanje, Tzanelli \& Clayton, 2014). In 2015 FIFA was to be engulfed in scandals of its own, adding to the negative associations surrounding its events in the longer term. Certainly the 2014 tournament had showcased much of what is positive about 
the host country. But while total tourist numbers had been rising up until 2014, thereafter numbers fell and the contribution to the economy flattened (WTTC, 2017) in complete contrast to what had been expected pre event (Jainchill, 2013). There is evidence that sports media can have a negative influence over tourism intention (Chalip et al., 2003) and we add to that in the case of the World Cup.

\subsection{Implications}

The imagery from holding the 2014 World Cup probably benefited Brazil because of the association with a world event but the main problem was the concomitant exposure to damaging media commentary (Buarque, 2015) which then produced a larger, negative effect. One implication for practitioners is then to use such major events to promote a country only when the internal realities of that country are compatible with the desired external image. Those promoting major global sporting events need also to consider a wider view of legacy effects. Here FIFA could boast about legacy effects of the 2014 event on women's football and children's health (FIFA, 2015) but their report ignored the impact on a country where the legacy included unused stadia and cuts in social budgets. Reputation spill-over effects work in both directions and it may not be a coincidence that there was a greater focus on FIFA's own reputation from 2015 onwards.

Brazil's image for Warmth (trustworthy; sincere; honest; loyal) did not decline significantly on average whereas other aspects of NBP the country did. This not only re-emphasises the need to 
consider both cognitive and affective aspects of country imagery (Stylidis, Shani, \& Belhassen, 2017) but offers Brazil a platform for self-promotion going forward. Why such associations did not decline could also be the basis for further research.

Our work adds to a growing focus on the relevance of the personality dimension of Openness to Experience in tourism research but it is as yet unclear how tourism marketing might best apply such findings; further work is implied.

The implications for researchers include the need to view the effects of major events through a fine lens. The average opinion of stakeholders might be influenced positively or negatively but that should not be taken to imply, as we have demonstrated, that all will be so influenced or that any movement in the mean represent the true impact on groups of real interest, here those more likely to travel to the host country. 


\section{References}

Adidas (2014) 2014 World Cup already a success for Adidas. https://www.adidasgroup.com/en/media/news-archive/press-releases/2014/2014-fifa-world-cup-already-greatsuccess-adidas/ accessed February 2018

Ahn, T., Ekinci, Y., \& Li, G. (2013). Self-congruence, functional congruence, and destination choice. Journal of Business Research, 66, 719-723.

Anderson, N. H. (1971). Integration Theory and Attitude Change. Psychological Review, 78(3), 171-206

Anderson, N. H. (2013). Unified Psychology Based on Three Laws of Information Integration. Review of General Psychology, 17(2), 125-132

Bachion Ceribeli, H. \& Zuca de Souza, N.B. (2016). Imagem do Brasil e atitudes dos consumidores sul-africanos. Revista Pensamento Contemporâneo em Administração, 10(1), 5061

Baker, D.A., \& Crompton, J.L. (2000). Quality, satisfaction and behavioral intentions. Annals of Tourism Research, 27(3), 785-804.

Balasubramanian, S. K. (1994). Beyond advertising and publicity: Hybrid messages and public policy issues. Journal of Advertising, 23 (4), 29-46.

Baloglu, S., \& McCleary, K. (1999). A model of destination image formation. Annals of Tourism Research, 26(4), 868-897.

Baumann, R., \& Matheson, V. (2018). Mega-events and tourism: The case of Brazil. Contemporary Economic Policy, 36(2), 292-301.

Beasley, F.M. \& Shank, M.D. (1998). Fan or fanatic: refining a measure of sports involvement, Journal of Sport Behavior. 21(4), 435-43.

Buarque, D. (2015) One country, two cups - The international image of Brazil in 1950 and in 2014: A study of the reputation and the identity of Brazil as projected by the international media during the two FIFA World Cups in the country, International Journal of Communication, 9, 1300-1318

Bujisic, M., Bilgihan, A., \& Smith, S. (2015). Relationship between guest experience, personality characteristics, and satisfaction: Moderating effect of extraversion and openness to experience. Tourism Analysis, 20(1), 25-38. 
Butler, B.N. \& Aicher, T.J. (2015). Demonstrations and displacement: social impact and the 2014 FIFA World Cup. Journal of Policy Research in Tourism, Leisure and Events, 7(3), 299-313.

Chalip, L., Green, B.C. \& Hill, B. (2003). Effects of sport event media on destination image and intention to visit. Journal of Sport Management, 17(3), 214-234.

Chari T. (2015). Discursive constructions of the Germany-Brazil semifinal match during the FIFA 2014 World Cup: The limits of football as a soft power resource, Communicatio, 41(4), 405-422

Choi, J. G., Tkachenko, T., \& Sil, S. (2011). On the destination image of Korea by Russian tourists. Tourism Management, 32(1), 193-194.

Cohen, J. (1988). Statistical power analysis for the behavioral sciences (2nd ed.), Hillsdale, Lawrence Erlbaum Associates, NJ.

d'Astous, A. \& Boujbel, L. (2007). Positioning countries on personality dimensions: Scale development and implications for country marketing, Journal of Business Research, 60 (3), 231239.

Davies, G., Rojas-Méndez, J. I., Whelan, S., Mete, M., \& Loo, T. (2018). Brand personality: Theory and dimensionality. Journal of Product \& Brand Management, 27(2), 115-127.

Dholakia, U.M. (2001). A motivational process model of product involvement and consumer risk perception. European Journal of Marketing, 35 (11/12), 1340-1362.

Dimanche, F. (1990). Measuring involvement in recreational and touristic contexts with the involvement profUe scale. Unpublished dissertation. University of Oregon.

Falk, R. F., \& Miller, N. B. (1992). A primer for soft modeling. Akron, Ohio: University of Akron Press.

FIFA (2015) Brazil 2014, a success for the entire football community, http://www.fifa.com/about-fifa/news/y=2015/m=3/news=brazil-2014-a-success-for-the-entirefootball-community-2568019.html accessed Feb 2018

Fourie, J., \& Santana-Gallego, M. (2011). The impact of mega-sport events on tourist arrivals. Tourism Management, 32(6), 1364-1370.

Gerber, A.S., Huber, G.A., Doherty, D. and Dowling, C.M. (2011). Personality traits and the consumption of political information. American Politics Research, 39(1), 32-84.

Getz, D., \& Fairley, S. (2003). Media management at sport events for destination promotion: Case studies and concepts. Event Management, 8(3), 127-139. 
Getz, D., \& Page, S. J. (2016). Progress and prospects for event tourism research. Tourism Management, 52, 593-631.

Gibson, H., Qi, C., \& Zhang, J. (2008). Destination image and intent to visit China, and the 2008 Beijing Olympic Games. Journal of Sport Management, 22(4), 427-450.

Giraldi, J.D.M.E., Maheshwari, V., Mariutti, F. and Konstantopoulou, A. (2017). Role of attitudes in Brazil's country brand image. International Journal of Business and Globalisation, 21(3), 297307.

Goldenberg, J., Libai, B. Moldovan, S. \& Muller, E. (2007). The NPV of bad news. International Journal of Research in Marketing, 24(3), 186-200.

Gosling, S. D., Rentfrow, P. J., \& Swann Jr, W. B. (2003). A very brief measure of the Big-Five personality domains. Journal of Research in Personality, 37(6), 504-528.

Guina, F.D.T.C. \& Giraldi, J. D.M.E. (2015). The country of origin effect on Brazilian beef trade in Europe: The moderating role of gender, age, and product involvement. Journal of Food Products Marketing, 21(2), 123-140.

Guina, F.D.T.C. \& Giraldi, J.D.M.E. (2012). Differences on the image of Brazil in external Markets according to consumers' age, gender, knowledge about the country and country of residence. International Journal of Business Science and Applied Management, 7(2), 13-28.

Gurhan-Canli, Z., \& Maheswaran, D. (2000). Determinants of country-of-origin evaluations. Journal of Consumer Research, 27(1), 96-108.

Gwinner, K.P. \& Eaton, J. (1999). Building brand image through event sponsorship: The role of image transfer. Journal of Advertising, 28(4), 47-57.

Han, H., Hsu, L. T. J., \& Lee, J. S. (2009). Empirical investigation of the roles of attitudes toward green behaviors, overall image, gender, and age in hotel customers' eco-friendly decisionmaking process. International Journal of Hospitality Management, 28(4), 519-528.

Hayes, A. F. (2017). Introduction to mediation, moderation, and conditional process analysis. Second Edition. Guilford Press: New York.

Herz, M., \& Arnegger, J. (2017). Country image formation, stability, and change: a longitudinal assessment of consumers' image of Azerbaijan. Journal of Travel \& Tourism Marketing, 34(9), 1169-1183.

Heslop, L. A., Nadeau, J., \& O'Reilly, N. (2010). China and the Olympics: views of insiders and outsiders. International Marketing Review, 27(4), 404-433. 
Herz, M. \& Arnegger, J. (2017). Country image formation, stability, and change: a longitudinal assessment of consumers' image of Azerbaijan. Journal of Travel \& Tourism Marketing, 34(9), 1169-1183.

Huang, J \& Chen, Y. (2006). Herding in online product choice. Psychology \& Marketing, 23 (5), 413-428

Jaffe, E. D. \& Nebenzahl, I. (2006). National Image \& Competitive Advantage: The Theory \& Practice of Place Branding, 2/e, Copenhagen: Copenhagen Business School Press.

Jainchill, J. (2013). Brazil efforts touts diversity in run-up to World Cup, Olympics. http://www.travelweekly.com/South-America-Travel/Brazil-effort-touts-diversity-in-run-up-toWorld-Cup-Olympics/.

Jost, J.T. (2006). The end of the end of ideology. American Psychologist, 61(7), 651-70.

Kamins, M. A., \& Gupta, K. (1994). Congruence between spokesperson and product type: A matchup hypothesis perspective. Psychology \& Marketing, 11(6), 569-586.

Kim, Y. K., Shim, S. W., \& Dinnie, K. (2013). The Dimensions of Nation Brand Personality: A Study of Nine Countries. Corporate Reputation Review, 16(1):34-47.

Kim, S.S. and Morrsion, A.M. (2005). Change of images of South Korea among foreign tourists after the 2002 FIFA World Cup. Tourism Management, 26(2), 233-247.

Korstanje, M.E., Tzanelli, R. \& Clayton, A. (2014). Brazilian World cup 2014: Terrorism, tourism, and social conflict. Event Management, 18(4), 487-491.

Kroloff, G. (1988). At home and abroad: Weighing In, Public Relations Journal, 44 (8), 8-10.

Li, X. R., \& Kaplanidou, K. K. (2013). The impact of the 2008 Beijing Olympic Games on China's destination brand: A US-based examination. Journal of Hospitality \& Tourism Research, 37(2), 237-261

Lee, Y.K., Kim, S., Lee, C.K. \& Kim, S.H. (2014). The impact of a mega event on visitors' attitude toward hosting destination: Using trust transfer theory. Journal of Travel \& Tourism Marketing, 31(4), 507-521.

Lee, R., Lockshin, L., \& Greenacre, L. (2016). A memory-theory perspective of country-image formation. Journal of International Marketing, 24(2), 62-79.

Lopes, I.B., Giraldi, J.D.M.E. and Aguiar, L.K. (2014). An analysis of country image of Brazil and Its fresh fruits: A two scales comparison. Journal of Food Products Marketing, 20(3), 262-282. 
Mariutti, F. \& Tench, R. (2016). How does Brazil measure up? Comparing rankings through the lenses of nation brand indexes. Place Branding and Public Diplomacy, 12(1), 17-31.

Mariutti, F.G., Giraldi, J.D.M.E. \& Crescitelli, E. (2013). The image of Brazil as a tourism destination: an exploratory study of the American market. International Journal of Business Administration, 4(1), 13-22.

McCrae, R.R. (1996). Social consequences of experiential openness. Psychological bulletin, 120(3), 323-37.

Mitra, A. (2015). An ethical analysis of the 2014 FIFA World Cup in Brazil. Law \& Business. Review of the Americas, 21, 3-18.

Moreover (2014). http://moreover.com/blog/2014/07/14/2014-world-cup-media-coverageinfographic/\#.VJD69010ypp

Müller, M. (2015). What makes an event a mega-event? Definitions and sizes. Leisure Studies, 34(6), 627-642.

Neto (2014) The 2014 FIFA World Cup: Copa das Copas - A Success Story. Huffington Post online.http://www.huffingtonpost.co.uk/vicente-neto/world-cup b 5584086.html accessed February 2018.

Noelle-Neumann, E. (1993) The spiral of silence: Public opinion - our social skin (2nd ed.), Chicago: University of Chicago Press.

Nye, J.S., 1990. Soft power. Foreign policy, 80, pp.153-171.

Osgood, C. E., \& Tannenbaum, P. H. (1955). The principle of congruity in the prediction of attitude change. Psychological Review, 62(1), 42-55.

Pike, S. (2016). Destination image: Identifying baseline perceptions of Brazil, Argentina and Chile in the nascent Australian long haul travel market. Journal of Destination Marketing \& Management, 5(2), 164-170.

RI (2017) Reputation Institute, Country RepTrak ${ }^{\circledR}$ 2017, accessed online February 2018

Rojas-Méndez, J. I., Murphy, S. A. \& Papadopoulos, N. (2013). The U.S. brand personality: A Sino perspective, Journal of Business Research, 66(8), 1028-1034.

Rojas-Méndez, J.I. \& Papadopoulos, N. (2012). Argentine consumers' perceptions of the U.S. brand personality, Latin American Business Review, 13(4), 329-345. 
Rojas-Méndez, J. I., Papadopoulos, N. \& Murphy, S. A. (2013). "Measuring and Positioning Nation Brands: A Comparative Brand Personality Approach", Corporate Reputation Review, 16(1): 48-65.

Selstad, L. (2007). The social anthropology of the tourist experience. Exploring the "middle role". Scandinavian Journal of Hospitality and Tourism, 7(1), 19-33.

Sibley, C.G. \& Duckitt, J., (2008). Personality and prejudice: A meta-analysis and theoretical review. Personality and Social Psychology Review, 12(3), 248-279.

Soares e Castro, A. (2013). 2014 FIFA World Cup and 2016 Olympic Games: Brazil's strategy to win hearts and minds through sports and football. Public Diplomacy Magazine, 29-35.

Song, Y.-A., \& Sung, Y. (2013). Antecedents of Nation Brand Personality. Corporate Reputation Review, 16(1): 80-94.

Sun, Q. and Paswan, A., (2012). Country branding through Olympic games. Journal of Brand Management, 19(8), 641-654.

Stylidis, D., Shani, A. \& Belhassen, Y. (2017). Testing an integrated destination image model across residents and tourists. Tourism Management, 58,184-195.

Tybout, A.M., Calder, B.J. \& Sternthal, B. (1981). Using information-processing theory to design marketing strategies. Journal of Marketing Research, 28 (February), 73-79.

Van Dijk, T. (1996). Discourse, power and access. In C. R. Caldas-Coulthard and M. Coulthard (Eds.), Texts and practices: Readings in critical discourse analysis (pp. 84-104). London: Routledge.

Van Langenhove, L. \& Harré, R. (1995). Cultural stereotypes and positioning theory. Journal for the Theory of Social Behaviour, 24: 359-372

Wang, S., Beatty, S. E., \& Mothersbaugh, D. L. (2009). Congruity's role in website attitude formation. Journal of Business Research, 62(6), 609-615.

Wanta, W., Golan, G. \& Lee, C. (2004). Agenda Setting and International News: Media Influence on Public Perceptions of Foreign Nations, Journalism \& Mass Communication Quarterly, 81(2): 364-377.

WTTC (2017) Travel and Tourism Economic Impact 2017 Brazil, World Travel and Tourism Council. Available athttps://www.wttc.org/-/media/files/reports/economic-impactresearch/countries-2017/brazil2017.pdf. Accessed February 2018 
Wyatt, R. O. \& Badger D. P. (1984). How reviews affect interest in and evaluation of films. Journalism Quarterly. 61(4) 874-878.

Zavattaro, S. M., \& Fay, D. L. (2019). Brand USA: A natural quasi-experiment evaluating the success of a national marketing campaign. Tourism Management, 70, 42-48. 


\section{Appendix}

\section{Attitude and Intentions toward Brazil (Pre and Post World Cup)}

\begin{tabular}{|c|c|c|c|c|c|c|}
\hline & \multicolumn{3}{|c|}{ Pre-world cup } & \multicolumn{3}{|c|}{ Post world cup } \\
\hline & mean & s.d & $\alpha$ & mean & s.d. & $\alpha$ \\
\hline $\begin{array}{l}\text { Overall Attitude } \\
\text { Overall, I like Brazil } \\
\text { I think Brazil is a model country } \\
\text { I admire Brazil } \\
\text { I have a very good image of Brazil }\end{array}$ & 3.30 & .85 & 0.88 & 3.16 & .76 & 0.84 \\
\hline $\begin{array}{l}\text { Tourism Intentions } \\
\text { A trip to Brazil will be a lot of fun } \\
\text { Brazil is a place popular with travellers } \\
\text { I would recommend going to Brazil to others } \\
\text { Brazil is a place one has dreamed of visiting } \\
\text { I would like to visit Brazil }\end{array}$ & 3.69 & .76 & 0.82 & 3.50 & .76 & 0.83 \\
\hline
\end{tabular}

Source: Rojas-Mendez, Murphy \& Papadopoulos, 2013

For both measures respondents were asked: Please click in the option that best represents your opinion regarding BRAZIL and responded on a 5 point scale anchored on $1=$ strongly disagree, 5 = strongly agree.

Brand Personality Dimensions

\begin{tabular}{|l|c|c|c|c|c|c|}
\hline \multicolumn{1}{|c|}{ Dimension and Items } & \multicolumn{3}{c|}{ Pre-world Cup } & \multicolumn{3}{c|}{ Post World Cup } \\
\cline { 2 - 7 } & $\boldsymbol{\alpha}$ & mean & s.d. & $\boldsymbol{\alpha}$ & mean & s.d. \\
\hline $\begin{array}{l}\text { Warmth } \\
\text { Trustworthy; Sincere; Honest; Loyal }\end{array}$ & .82 & 3.05 & .70 & .86 & 3.04 & .76 \\
\hline $\begin{array}{l}\text { Competence } \\
\begin{array}{l}\text { Enterprising; Future Oriented; } \\
\text { Innovative; Achievement oriented }\end{array}\end{array}$ & .86 & 3.48 & .81 & .88 & 3.38 & .80 \\
\hline $\begin{array}{l}\text { Status } \\
\text { Sophisticated; Elegant; Posh; Refined }\end{array}$ & .78 & 3.03 & .74 & .79 & 2.95 & .71 \\
\hline
\end{tabular}

Source: Rojas-Mendez, Papadopoulos \& Murphy, 2013

For all measures respondents were told: Assume for a minute that a country is a living person, what would this reflect in your mind? Now, thinking about Brazil, please choose the option that best represents your opinion on the degree that Brazil, as a person, projects each of the following characteristics and asked to respond on a 5 point scale anchored on 1= strongly disagree, 5 = strongly agree 
Football Involvement inventory Items (Beasley \& Shank, 1998)

To me, football is:

\begin{tabular}{|c|c|c|c|c|c|c|c|c|c|}
\hline & & 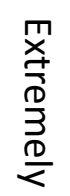 & $\frac{\grave{D}}{2}$ & 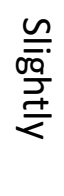 & 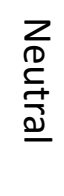 & 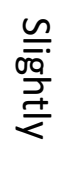 & $\frac{\mathbb{D}}{2}$ & 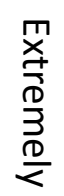 & \\
\hline 1 & Boring & 1 & 2 & 3 & 4 & 5 & 6 & 7 & Exciting \\
\hline 2 & Interesting & 1 & 2 & 3 & 4 & 5 & 6 & 7 & Uninteresting \\
\hline 3 & Valuable & 1 & 2 & 3 & 4 & 5 & 6 & 7 & Worthless \\
\hline 4 & Appealing & 1 & 2 & 3 & 4 & 5 & 6 & 7 & Unappealing \\
\hline 5 & Useless & 1 & 2 & 3 & 4 & 5 & 6 & 7 & Useful \\
\hline 6 & Not needed & 1 & 2 & 3 & 4 & 5 & 6 & 7 & Needed \\
\hline 7 & Irrelevant & 1 & 2 & 3 & 4 & 5 & 6 & 7 & Relevant \\
\hline 8 & Important & 1 & 2 & 3 & 4 & 5 & 6 & 7 & Unimportant \\
\hline
\end{tabular}

Note: Items 2, 3, 4, and 8 are reverse scored, alpha $=.96$.

Openness to Experience (Gosling, Rentfrow \& Swann, 2003).

Items: Open to new experiences, conventional $(R)$ and uncreative $(R)$

Anchor points $1=$ very much in disagreement 5 = very much in agreement

Note: Several studies have used the TIPI scale and found it satisfactory on a wide range of

psychometric criteria and favourably compared with other measures (e.g., Slatcher and

Vazire 2009) other than Cronbach alpha, a limitation recognized by the authors who warned

that TIPI was not designed with reliability criteria in mind. Rather, the goal of TIPI was to create a very short instrument that optimized validity (including content validity).

News valence (post World Cup survey only)

From the news you heard or watched about Brazil during the recent world cup was this positive or negative. 7 point scale $1=$ very negative and 7 = very positive. 